\title{
The use of blogs for political campaigning in a developing country context: the case of South Africa
}

\author{
OO BANKOLE, W CHIGONA AND FO BANKOLE.
}

\begin{abstract}
All over the world, the use of the digital platform for political campaigning is growing. This development has the potential to empower the electorate to engage in political debate. This exploratory research aims at investigating the impacts and implications of blogging in the 2009 election campaign in South Africa. The study attempts to answer the following questions: What is the nature of the campaign blogosphere? What are the key issues addressed in the blogs? This study employed content analysis to identify the key concepts in the blogs posted during South Africa's 2009 National and Provincial Elections. Data was gathered from the blogs of four different South African web log feeds. The coding method used in this study is priori coding, based on the concept of Cornfield, Carson, Kalis \& Simon (2005), and Stanyer (2006). Findings show that, in South Africa, the use of blogging for political campaigning is still in its infancy. South African bloggers are mainly politicians, journalists and other media personnel who discuss high level political issues. The study notes a limited participation by ordinary citizens in political blogging.
\end{abstract}

Keywords: blogs, blogging, content analysis, political campaign, South Africa

Disciplines: Information Systems Studies, Communications Studies, Political Studies

\section{Introduction}

The use of web tools is creating opportunities for the exchange of information, ideas and debates in the form of teledemocracy among people (Price \& Cappella, 2002). The common web tools employed for sharing information and ideas include podcasts, web logs (i.e. blogs) and wikis (Boulos, Maramba \& Wheeler, 2006). Web tools are increasingly becoming a vital and integrated part of political campaigns in many countries (William, Trammell, Postelnicu, Landreville \& Martin, 2005). Several studies have shown the use of websites and web tools in political campaigns (Stromer-Galley, 2000; Hansen \& Benoit, 2002; Auty, 2004; William et

The authors are attached to the department information systems, University of Cape Town, Rondebosch 7701, South Africa. An earlier version of this paper appeared in the Proceedings of a 2010 International Conference on Information Management and Evaluation. This paper was substantially, revised based on the feedback from the conference and comments from the reviewers of the journal. Corresponding author: Wallace Chigona, Wallace.chigona@uct.ac.za. 
al., 2005; Stanyer, 2006). In the South African context, the use of the web for online campaigning is just emerging. In the 2009 General Elections, various web-based technologies and innovations were used. The public was involved with the online campaign process through blogs and online forums. For instance, images of the ruling African National Congress (ANC) president, Jacob Zuma, could be downloaded from the ANC website, and the campaign rallies of the main opposition the Democratic Alliance (DA) leader, Helen Zille, was broadcast on Twitter (Mafirakurewa, 2009). Furthermore, several political parties used various means to disseminate information to the public through several Web 2.0 technologies for their campaign. Using the case of the 2009 South African General Elections, this study focuses on the use of blogs in political campaigns as a forum for public debate and politics in a developing country context (Drezner \& Farrell, 2004).

Blogging affords political candidates and different interest groups an avenue to express their opinions (William et al., 2005). Blogging for political campaigns is ever increasing, in both developed and developing countries. In the United States of America (USA), the use of blogs for political campaigning became prominent in 2004 (William et al., 2005). Other cases where blogging has been used in the political context include Denmark and Britain, both in 2005 (Stanyer, 2006; Klastrup \& Pedersen, 2006), in China for political discussions since 2002 (MacKinnon, 2008), and in the 2005 Presidential Elections in Egypt (Mehana, 2008).

Studying the use of web-based tools such as blogs in South Africa is particularly interesting, considering the low penetration rate of the Internet. In 2009, the Internet penetration in South Africa was only 10\% of the population (Africapedia, 2011). This translates to only a small proportion of voters having access and skills to use the Internet. It is therefore worth asking the nature of use and level of engagement in such a context. At the same time, there has been recent development in the undersea cable, as well as a growing mobile Internet penetration point for growing Internet access for the population. For example, there was an increase in the number of Internet users from 10\% in 2009 to 13,9\% in 2011, the latter consisting of about 6,8 million Internet users (Internet World Stats, 2011). Therefore, the findings of this study can serve to contribute towards the nature and future growth of the use of blogging for political campaigning.

This research aims to answer the question: What is the nature of use and implications of blogging in election campaigning in South Africa? The study presents some areas of discussion such as: What is the nature of the campaign blogosphere? What are the key issues addressed in the blogs? This study makes a theoretical and practical contribution to that discourse.

To provide holistic answers to questions around the use technology for political campaign requires a transdisciplinary approach. Transdisciplinality involves drawing from knowledge from different disciplines to studying a phenomena in order to get a holistic view (van Biljon, 2011). The use of blogging for political campaign essentially transforms the blogging space into a political arena where the actors are employing political strategies to out manoeuvre their political opponents. Studying the political strategies and political consequences of such an engagement would draw upon knowledge from the discipline of Political Sciences. At the same time, the impact of the technology (i.e. blogging) on the political space would draw from Information Systems and Communication Studies disciplines. While this study does not achieve all that, the study contributes towards a debate in that interdisciplinary space. 


\section{South Africa in context}

South African Parliamentary General Elections are conducted every five years. At each voting a voter casts two votes: one for the National Assembly and one for the respective province. The country uses a proportional representation-based electoral system (Crossland \& Chigona, 2010). In a proportional representation voting system, the voter votes for a party (as opposed to individual candidates for the respective constituencies) and the number of parliamentary seats for a party is in direct proportion to the number of votes the party receives. The political parties are responsible for deciding the actual members who go to parliament (Crossland \& Chigona, 2010). Local government elections are held separately from the national and provincial elections.

The 2009 General Election was the fourth democratic election since the end of apartheid in 1990. South Africa is a multi-political party democracy, with 117 political parties registered at national/provincial level to take part in the 2009 election (EISA, 2009). However, 42 parties submitted candidates' lists while a total of 28 political parties contested seats in the National Assembly election, of which 11 parties eventually contested for the National Assembly and all nine Provincial Legislatures (EISA, 2009). The distribution of the parliamentary seats is presented in Table 1, to show an overview of the political party structure in South Africa. As will be shown later, our study focused on the three biggest parties - the ANC, the DA and the Congress of the People (COPE).

Table 1: Distribution of the parliamentary seats among the South African political parties (Source: Parliamentary monitoring group, 2009)

\begin{tabular}{|l|l|}
\hline Political party & $\begin{array}{l}\text { Number of National Assembly parliamentary } \\
\text { seats (2009) }\end{array}$ \\
\hline African National Congress (ANC) & 264 \\
\hline Democratic Alliance (DA) & 67 \\
\hline Congress of the People (COPE) & 30 \\
\hline Inkatha Freedom Party (IFP) & 18 \\
\hline United Democratic Movement (UDM) & 4 \\
\hline Freedom Front Plus (FF Plus) & 4 \\
\hline Independent Democrats (ID) & 4 \\
\hline African Christian Democratic Party (ACDP) & 3 \\
\hline United Christian Democratic Party (UCDP) & 2 \\
\hline Azanian People's Organisation (AZAPO) & 1 \\
\hline Minority Front (MF) & 1 \\
\hline Pan Africanist Congress (PAC) & 1 \\
\hline African Peoples' Convention (APC) & 1 \\
\hline
\end{tabular}

The number of registered South African voters in the country in 2009 was $23,181,997$. The general level of voter turnout in the 2009 elections was $77 \%$ of the registered voters.

There is still a paucity of studies on the use of web tools for political campaigns in other developing countries. In South Africa, previous studies have investigated the use of web tools such as websites and the Internet in political campaigns. Crossland \& Chigona (2010) assessed the functionality and delivery of South African political parties' websites. The study showed that websites of larger parties normally offer more functionality than those of smaller parties. In addition, Onumajuru \& Chigona (2010) examined the use of the Internet for 
political campaign communication in South Africa, although there were other political campaign tools such as cell phones, newspapers, rallies and televisions employed during the 2009 election. For example, several parties used cell phones to send short messages (SMSs) directly to citizens to mobilise support and spread their respective parties' political positions on issues. SMSs serve also as a mechanism for collecting fees or donations. A major trend in the use of the cell phone is the adoption of mobile donations whereby a supporter (e.g. of the DA, ACDP and COPE parties) sends an SMS to a premium rate number to make a onceoff donation of R10, R30 or a monthly contribution of R50 (BulkSMS, 2009). Other usages of the cell phone during the 2009 campaigns were:

- The use of SMS to pay membership fees

- Provision of election officials' cell phone numbers on the party's website to provide access to political leaders (e.g. the ACDP and COPE parties)

- To motivate party supporters to the elections website to poll their vote by sending the SMS of the party's abbreviation to a short code (e.g. DA)

- To persuade youths to express their opinion through SMS (e.g. ID)

- To ensure that voters receive regular party news on their cell phone and could send an SMS alert to their party on the problems in their communities (e.g. DA) (BulkSMS, 2009).

However, the studies showed that the majority of the political parties in South Africa employed the Internet as a means of campaign communication (Onumajuru \& Chigona, 2010; Crossland \& Chigona, 2010). Despite the low Internet penetration in South Africa in 2009, these two studies showed the use of web tools for political campaigns. However, both studies did not focus on the use of blogs for political campaigns. Hence, this study makes a contribution by focusing on blogging as a political campaign tool.

\section{Blogging}

A blog is essentially a web page for sharing information with entries which can be linked to other web pages (Schiano, Nardi, Gumbrecht \& Swartz, 2004; Boulos et al., 2006). Blogs are arranged in dated reverse sequential order (i.e. reverse journaling and archive entries). A blog performs the function of an online journal and diary (William et al., 2005; Boulos et al., 2006). In comparison to other web tools, blogs have the potential to engage public readership through online postings and linking of messages to other sites. This allows for an amalgamation of links to news, commentary and thoughts (Lin, Halavais \& Zhang, 2007). Blogs are used to express and access information which is based on personal opinion. The process of updating entries in the blog on the web is referred to as blogging, while the author of the blog is a blogger (Gill, 2004). Blogging is increasingly used in journalism, mass media, education and politics. It is a cost effective means of disseminating information that requires no editorial supervision. It is a mainstream provider of information that has a positive influence on the media.

The impact of blogging on political campaigns has been investigated in many countries. Blogging has been employed in all presidential campaigns in the USA since the year 2004 (Stanyer, 2006). In the USA, blogs were seen as the most effective web communication tools for political campaign (Williams et al., 2005). In the 2004 USA election, blogs were used to 
mobilise groups for election through common efforts (Williams et al., 2005). The use of blogs has created avenues for politicians to raise funds, mobilise volunteers and spread messages to the citizens (Cornfield et al., 2005). Blogging is currently becoming a vital tool for political campaigning in Britain (Stanyer, 2006).

\section{$4 \quad$ Research methodology}

The study adopted a qualitative research approach in sourcing and analysing the data. Content analysis was employed to analyse the blogs. The study used priori coding i.e. the categories are set prior to the analysis and are based on an adopted concept (Weber, 1990). The coding was structured based on the concept developed by Cornfield et al. (2005) and Stanyer (2006). The coding concepts were structured as follows:

- The bloggers were categorised according to their political orientation.

- The bloggers were categorised according to the organisation to which they belonged.

- The emphasised keywords in the blog posts were identified as the Key Word in Context (Stemler, 2001).

- The frequency of the keywords established their frequency in the blog posts.

Further, the blog posts were sorted into four opinion groups:

1. criticism of the opposition,

2. responding to criticism of the opponent,

3. supporting other people's opinions and ideas, and

4. making a statement on the campaign (Stanyer, 2006).

Coder reliability of the keywords and concepts were tested for consistency and stability of the generated categories. The categories were created under test-retest conditions i.e. the same coder rereads the data and recategorises the same data after some time has elapsed (Krippendorff, 2004, p. 215). To ensure greater intercoder (i.e. more than one coder analysing the data) agreement and higher reliability, another coder was requested to identify and recategorise the same data. The coefficient of reliability was determined using Krippendorff's $\alpha$ (alpha reliability) i.e. a statistical measure of the intercoder agreement attained when coding data. The measure is commonly used in the content analysis research method (Krippendorff, 2007). All the differences in categories were reconciled and agreed upon. The coefficient of reliability was found to be 0,85 and the intercoder agreement was $85 \%$.

The data was gathered from four blog sites, the Mail \& Guardian (M\&G) Online's "Thought Leader" (www.thoughtleader.co.za/category/politics/) and the three largest political parties in the country. The Thought Leader was selected because of its prominence as a blogging platform in South Africa. M\&G Online was rated by Afrigator (Africa social media directory) as the top blog site in South Africa. The blog posts were accessed between the period of February 2, 2009 and April 22, 2009. The M\&G blog site was searched for blog posts containing the terms "political campaign", "South African Election" and "2009 Election". The search returned 90 blog posts out of which 13 were relevant and addressed the 2009 election campaign. 
The three political parties used in the study were those which had most seats in Parliament: the ANC (the ruling party); COPE (a newly formed political party which was termed as an "anti [President] Zuma party") and the DA (the main opposition party). For these parties:

- Thirteen blog posts were posted on the administrator blog on the DA blog site, of which eight were relevant to the political campaign.

- Seven blog posts on the ANC website were distributed among five blogs.

- Three blog posts were posted on three different blogs on the COPE blog site.

Altogether, 23 blog posts were gathered, out of which 18 blog posts were relevant to the study. Only the relevant blogs were used in the study. The list of blog posts gathered for this study is listed in the Appendix. Table 2 summarises the number of data sourced.

Table 2: $\quad$ Summary of blog posts considered

\begin{tabular}{|l|l|l|l|}
\hline & Media blog posts & Political blog posts & Total \\
\hline Blog posts collected & 90 & 23 & 113 \\
\hline Relevant blog posts & 13 & 18 & 31 \\
\hline Number of blogs & 5 & 9 & 14 \\
\hline
\end{tabular}

The blogs used in this study were those dated between $13^{\text {th }}$ February 2009 and 22nd April 2009; this was the period that the election campaign was at its peak. The elections were held on the $22^{\text {nd }}$ April 2009.

\section{$5 \quad$ Findings}

\subsection{The South African campaign blogosphere}

The size of the South African campaign blogosphere was relatively small, compared to that of the USA and Britain. This is not surprising, considering the low penetration of the Internet in South Africa. Again, it was noted that a large number of blogs posted within the political campaign period did not deal with the election issues. For example, out of the $113 \mathrm{blog}$ posts selected from the specified period, only 31 messages (27\%) were relevant to the political campaign. The remaining $73 \%$ dwelt on other on-going social/general issues. This is interesting, considering that all the political parties had a website and they had used the websites for the campaign (Crossland \& Chigona, 2010). This indicates that the use of blogs for political campaigning was probably still in its infancy and political parties had not fully embraced the use of interactive online tools.

The bloggers in our sample were categorised according to the political orientation identified from the main objective of their blogs. The bloggers from the political blog feeds were classified as partisans; these showed a fervent support of their political parties through their messages. The bloggers from the media, who were mainly journalists, were labelled as nonpartisans. Those in this category were generally free from party affiliation or bias and their blog messages reflected no commitment to any political parties. The search did not yield any blogs from the general public on the political campaign. Table 3 shows the classification of the bloggers. 
Table 3: $\quad$ Categorisation of the bloggers according to their political orientation and organisations

\begin{tabular}{|l|l|l|l|}
\hline \multirow{5}{*}{ Orientation } & Blogs & Keywords & $\begin{array}{l}\text { Number of } \\
\text { relevant blog } \\
\text { posts }\end{array}$ \\
\hline \multirow{5}{*}{ Partisan } & Jessie Duarte (ANC) & Right to vote & 2 \\
\cline { 2 - 4 } & Janet Love (ANC) & Corruption, crime & 1 \\
\cline { 2 - 4 } & $\begin{array}{l}\text { Nozizwe Madlala } \\
\text { (ANC) }\end{array}$ & $\begin{array}{l}\text { Women's rights, equality, security, } \\
\text { employment }\end{array}$ & 1 \\
\cline { 2 - 4 } & Naledi Pandor (ANC) & Education & 1 \\
\cline { 2 - 4 } & $\begin{array}{l}\text { Cyril Ramaphosa } \\
\text { (ANC) }\end{array}$ & Human rights, education & 2 \\
\cline { 2 - 4 } & COPE & Employment & 1 \\
\cline { 2 - 4 } & Ronald Kete (COPE) & Corruption, crime & 1 \\
\cline { 2 - 4 } & Masi Moyo (COPE) & Corruption, crime & 8 \\
\cline { 2 - 4 } & Administrator (DA) & Corruption, crime, security & 5 \\
\hline & Avishkar Govender & $\begin{array}{l}\text { Corruption, crime, security, } \\
\text { education, employment, human } \\
\text { rights }\end{array}$ & 3 \\
\hline & Alex Matthews & Policies, education, transformation & 1 \\
\cline { 2 - 4 } & Khadija Sharife & Policies & 3 \\
\cline { 2 - 4 } & Michael Trapido & Corruption, crime & 1 \\
\cline { 2 - 4 } & Hennie van Vuuren & Corruption & 3 \\
\hline
\end{tabular}

There was little diversity in the organisational fields and political orientation of the bloggers. Furthermore, the corpus consisted of more partisan than non-partisan bloggers. Naturally, the partisan bloggers' postings over the period were only relevant to their political campaign. A low participation of non-partisan bloggers indicates that the media was still not engaging in the political campaign debate by using the blogging platform. An analysis of the overall usage of blogging by the media would be informative.

\subsection{Keywords in context}

The analysis identified the following seven keywords in the blogs: corruption, human rights and equality, security, education, employment, policies and crime. The number of times each keyword occurs in the blog posts was recorded (see Table 5). This portrays the relevance of these words, since they were extensively used in the blogs. 
Table 4: $\quad$ Word frequency count

\begin{tabular}{|c|c|c|c|c|c|c|c|}
\hline$\frac{\infty}{\infty}$ & 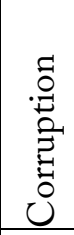 & : & 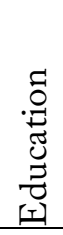 & 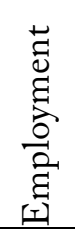 & 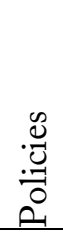 & 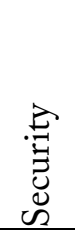 & 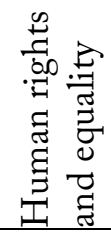 \\
\hline Jessie Duarte (ANC) & & & & & & & 2 \\
\hline Nozizwe Madlala (ANC) & & & & 1 & & 1 & 1 \\
\hline Janet Love (ANC) & 3 & 7 & & & & & \\
\hline Naledi Pandor (ANC) & & & 9 & & & & \\
\hline Cyril Ramaphosa (ANC) & & & 2 & & & & 1 \\
\hline COPE & & & & 6 & & & \\
\hline Ronald Kete (COPE) & 1 & 1 & & & & & \\
\hline Masi Moyo (COPE) & 1 & 2 & & & & & \\
\hline Administrator (DA) & 16 & 15 & & & & 5 & \\
\hline Hennie van Vuuren $(M \& G)$ & 14 & & & & & & \\
\hline Michael Trapido (M\&G) & 7 & 3 & & & & & \\
\hline Avishkar Govender (M\&G) & 2 & 4 & 1 & 1 & & 1 & 1 \\
\hline Alex Matthews (M\&G) & & & 1 & & 1 & & \\
\hline Khadija Sharife (M\&G) & & & & & 6 & & \\
\hline Total & 44 & 32 & 13 & 8 & 7 & 7 & 5 \\
\hline
\end{tabular}

Corruption was a major issue raised in the blogs during the election campaign. The term corruption occurred 44 times in the corpus. Seven of the blogs mentioned corruption in most of their messages. It was observed that blogs from the opposition parties (DA and COPE) emphasised corruption more than the other bloggers. The ANC mentioned corruption only in one blog. The DA administrator had the highest number of occurrences of 16, while Hennie van Vuuren $(\mathrm{M} \& \mathrm{G})$ had 14 occurrences. Michael Trapido $(\mathrm{M} \& \mathrm{G})$ took a liberal stance on the ANC and corruption issue, while Avishkar Govender (M\&G) spoke more on corruption and the need to address it. The DA administrator blog used the term in the context of attacking the ANC and as a campaign strategy i.e. to bring an end to corruption in the country. The other blogs from M\&G and COPE mentioned corruption in a similar context, thereby augmenting the concerns and issues raised by the DA, but from a liberal perspective.

With 32 occurrences (mentioned by six bloggers), crime was among the major issues raised in the blogs. Of all the bloggers, the DA Administrator mentioned crime the most. The ANC, COPE and M\&G blogs mentioned the keyword crime several times as well. The DA Administrator blog and bloggers from COPE (both being from members of political parties), used crime to attack the opposition and campaign for change. The remaining four blogs took on a liberal stance in addressing the issue.

Three blog posts mentioned security (i.e. Nozizwe Madlala (ANC), Avishkar Govender $(\mathrm{M} \& \mathrm{G})$ and the DA administrator). The word count for security in the corpus was seven. Three DA blogs mentioned the keyword - it was mentioned in the context of attacking the current system. Nozizwe Madlala mentioned security in the context of improving the current security system in the country, while Avishkar Govender only mentioned security in two blog posts, as it being a necessity in South Africa. 
The keyword policy appeared seven times in the corpus. Only two blogs from M\&G (Alex Matthews and Khadija Sharife) mentioned the policies of some of the political parties. Khadija Sharife $(M \& G)$ spoke more extensively in three different blog posts about the values, policies and stance of three political parties: the DA, the IFP and the ID. No partisan blogger mentioned policies. It can be surmised, therefore, that policies of political parties were not of much significance within blog discussions.

Education was mentioned in four blogs: the ANC (Naledi Pandor and Cyril Ramaphosa), and M\&G blogs (Avishkar Govender and Alex Matthews). The ANC dwelt extensively on the keyword education in their blogs. This may show that the ANC was concerned with education. Naledi Pandor (who was the Minister of Education) and Cyril Ramaphosa spoke about providing better education, as well as free schooling in the coming administration. Avishkar Govender $(M \& G)$ questioned the DA's education policy, while Alex Matthews (M\&G) supported that same policy.

Human right and equality appeared five times (in four blogs) in the corpus. Three of the bloggers were from the ANC and the fourth was Avishkar Govender (M\&G). The ANC blogs dwelt much on the right to vote, freedom, women and gender equality issues. Cyril Ramaphosa, Jessie Duarte and Nozizwe Madlala (all ANC) all spoke of human rights in various contexts, in terms of citizens' rights to vote and equality among South Africans. Avishkar Govender $(M \& G)$ mentioned the keyword in the context of making a subtle statement on how the DA acts as a liberal party.

Employment appeared eight times. The COPE blog stressed the need for creating more jobs. The keyword employment was constantly mentioned in Nozizwe Madlala's (ANC) and COPE's blogs. Both COPE blogs mentioned job creation in the context of empowering South Africans with more jobs opportunities. The ANC and M\&G also each had a blog which mentioned creating employment. Avishkar Govender $(M \& G)$ used the keyword in the context of challenging the DA party to show plans of improving living standards by providing employment.

\subsection{Classification into opinion groups}

It was noted that $3 \%$ of the bloggers posted messages in response to their opponents, $13 \%$ of the messages were classified as supporting others' opinions, $35 \%$ were described as criticising the opposition, $49 \%$ were those making a statement.

\section{Discussion and conclusions}

This study shows that, although blogging was employed in the 2009 political campaign in South Africa, its use was still in its infancy. From the analysis of the blogs posted during the political campaign, there were few participants with blog posts which were relevant to the election campaign. In addition, a close observation of activities on the blogs analysed revealed that blogging was not extensively utilised during the 2009 General Elections. A possible way to assess the effectiveness of the blogging as a political tool is to assess who is participating and who is not represented in that space. It was noted that the majority of the people who posted the blogs were either politicians or from the media fraternity. Those very people who had the traditional platform to set the election agenda, still had the power to set the agenda in the digital space. Here technology had not yet afforded the general electorate the 
opportunity to drive the political agenda; instead it perpetuated the power imbalance which exist in the real world.

The majority of the blogs posted within the campaign period did not focus on the political campaign. Most bloggers used their blogs to pass information and their opinions on other issues. There was no key blog message that stirred up reaction from the public.

Most issues on the blogs during the election campaign were centred on corruption, crime and employment. Corruption was the most frequently raised issue in the blogs. The issues noted as key in the blogs are similar to the ones raised on the websites, as noted by Crossland \& Chigona (2010) as well as Onumajuru \& Chigona (2010). This shows that the issues raised were important to the nation and were also being dealt with in other spaces. However, it was interesting to note the difference in emphasis on the different issues by different bloggers. Notably, the ANC did not comment much on corruption, crime and security, while the opposition parties emphasised these issues as the main points of failure of the ANC government. The ANC laid emphasis on education as an area on which they felt they had performed well; interestingly, the opposition did not address the issue of education. It would be informative to compare the nature of the political discourse on the blogging platform with the discourse on other platforms.

The study was exploratory, since there is still a paucity of studies focusing on the use of digital media in developing countries such as South Africa. The study had a number of limitations which future studies should seek to address. The findings are based on the blog postings. A qualitative research survey with political bloggers and the electorate would have shown how extensive the use of blogs was during the campaign. It would have portrayed important demographic information about the bloggers. Hence, future studies should explore the possible causes of limited participation by the general public in blogging on political issues. Furthermore, the study did not analyse the comments in response to the blog messages. Future studies need to be performed on these comments, in order to determine their correlation and significance on the blogs.

\section{References}

Africapedia (2011). Number of Internet Users in Africa 2011, Africapedia [online] http://www.africapedia.com/NUMBER-OF-INTERNET-USERS-IN-AFRICA-2011

Auty, C. (2004). "UK Elected Representatives and Their Weblogs: First Impressions”. Aslib Proceedings, Vol. 57, No. 4, pp. 338-355.

Boulos, M. N. K., Maramba, I. and Wheeler, S. (2006). "Wikis, Blogs and Podcast: A New Generation of Web-based Tools for Virtual Collaborative Clinical Practice and Education”. BMC Medical Education, 6(41). [online], www.biomedcentral.com/14726920/6/41

BulkSMS (2009). "SMS messaging is becoming politically correct" [online], http://bulksms.2way.co.za/w/BulkSMS-SMS-and-political-campaigning_170309.htm

Cornfield, M., Carson, J., Kalis, A. and Simon, E. (2005). "Buzz, Blogs, and Beyond: The Internet and the National Discourse in the Fall of 2004". [online], www.michelemiller.blogs.com/marketing to women/files/buzz blogs beyond.pdf 
Crossland, M. and Chigona, W. (2010). An Evaluation of the Functionality and Delivery of Websites of Political Parties in South Africa. SA Journal of Information Management 12(1), Art. \#453, 5 pages. DOI: 10.4102/sajim.v12i1.453 [online], http://www.sajim.co.za

Drezner, D. W. and Farrell, H. (2004). "The Power and Politics of Blogs". [online], www2.scedu.unibo.it/roversi/SocioNet/blogpaperfinal.pdf

EISA (2009). "Electoral Institute for the Sustainability of Democracy in Africa" [online], http://www.eisa.org.za/WEP/sou2009parties.htm

Gill, K. E. (2004). "How can we measure the influence of the blogosphere"? [online], www.faculty.washington.edu/kegill/pub/www2004_blogosphere_gill.pdf

Hansen, G. J. and Benoit, W. L. (2002). "Presidential Campaigning on the Web: The Influence of Candidate World Wide Websites in the 2000 General Election". [online], www.journalism.wisc.edu/blog-club/Site/Conners.pdf

Internet World Stats (2011). "Internet Usage and Population Statistics" [online], http://www.internetworldstats.com/stats1.htm

Klastrup, L. and Pedersen, P. S. (2006). "Blogging for Election: The Use and Function of Blogs as Communication Tool in a Danish Parliament Election Campaign”. [online], www.itu.dk/courses/DDRT/F2008/artikler/klastrup.pdf

Krippendorff, K. (2004). Content Analysis, an Introduction to Its Methodology, (2nd ed.), Sage Publications, Thousand Oaks, CA.

Krippendorff, K. (2007). "Computing Krippendorff's Alpha Reliablity", [online], http://repository.upenn.edu/cgi/viewcontent.cgi?article $=1043 \&$ context=asc papers

Lin, J., Halavais, A. and Zhang, B. (2007). "The Blog Network in America: Blogs as Indicators of Relationships among US Cities". Connections, Vol. 27, No. 2, pp. 15-23.

Lusoli, W., 2005, "A second-order medium? The Internet as a source of electoral information in 25 European countries”, Information Polity, Vol. 10, pp. 247-265.

MacKinnon, R. (2008). "Flatter World and Thicker Walls? Blogs, Censorship and Civic Discourse in China". Public Choice, Vol. 134, No. 1, pp. 31-46.

Mafirakurewa, M. (2009). "South Africa: Parties to Online to Campaign. The Africa News, [online], www.africanews.com/site/South_Africa_Parties_go_online_to_campaign

Mehana, O. (2008). "Internet and the Egyptian Public Sphere", [online], http://codesria.org/Links/conferences/general assembly12/papers/omnia mehanna.pd $\underline{\mathrm{f}}$

Onumajuru, P. U. and Chigona, W. (2010). The Use of the Internet for Electoral Campaign Communication by South African Political Parties. Proceedings $2^{\text {nd }}$ ICIME conference pp. 1-12.

Paliarmentary Monitoring Group. (2009). Number of Political Party Seats: National Assembly - May 2009, [online], www.pmg.org.za/node/16220

Price, V and Cappella, J. N. (2002). "Online Deliberation and its Influence: The Electronic Dialogue Project in Campaign 2000”. IT E Society, Vol. 1, No. 1, pp. 303-329. 
Schiano, D. J., Nardi, B. A., Gumbrecht, M. and Swartz, L. (2004). "Blogging by the Rest of Us”, [online], $\quad$ www.delivery.acm.org/10.1145/990000/986009/p1143schiano.pdf?key $1=986009 \&$ key2 $=4294181421 \&$ coll=GUIDE $\& d \mathrm{l}=$ GUIDE $\& C F I D=3$ 3783687\&CFTOKEN $=79737579$

Stanyer, J. (2006). "Online Campaign Communication and the Phenomenon of Blogging: An Analysis of Web Logs During the 2005 British General Election Campaign", Aslib Proceedings: New Information Perspectives, Vol. 58, No. 5, pp. 404-415.

Stemler, S. (2001). “An Overview of Content Analysis". Practical Assessment, Research $\xi^{\circ}$ Evaluation, Vol. 7, No. 17, [online], www.PAREonline.net/getvn.asp?v=7\&n=17

Stromer-Galley, J. (2000). “Online Interaction and Why Candidates Avoid It”. International Communication Association, Vol. 50, No. 4, pp. 111-132.

Weber, R. P. (1990). Basic Content Analysis, (2nd ed.), Sage Publications, Newbury Park, CA.

Van Biljon, J. 2011,'A critical review on the reporting of surveys in transdisciplinary research: a case study in Information Systems', Journal for Transdisciplinary Research in Southern Africa, vol. 7, no. 2, pp. 337 - 350 .

William, A. P., Trammell, K. D., Postelnicu, M., Landreville, K. D. and Martin, J. D. (2005). "Blogging and Hyperlinking: Use of the Web to Enhance Viability During the 2004 US Campaign.”.Journalism Studies, Vol. 6, No. 2, pp. 177-186.

Appendix

\begin{tabular}{|l|l|l|}
\hline & Mail \& Guardian (Thought Leader) blog feed & \\
\hline Blogs & Blog post title & Date posted \\
\hline Avishkar Govender & Adenhauer must make a decisive choice & $2009 / 02 / 21$ \\
\hline Avishkar Govender & A detailed review of the DA manifesto & $2009 / 02 / 27$ \\
\hline Michael Trapido & South Africa first, but I'm voting ANC & $2009 / 03 / 01$ \\
\hline Avishkar Govender & The Caring Society: My response & $2009 / 03 / 03$ \\
\hline Michael Trapido & ANC: Don't lose sight of the wood for the trees & $2009 / 03 / 08$ \\
\hline Michael Trapido & Give us an answer, NPA & $2009 / 03 / 19$ \\
\hline Avishkar Govender & One Nation with One Future (song words) & $2009 / 03 / 21$ \\
\hline Avishkar Govender & The great contender & $2009 / 04 / 09$ \\
\hline Khadija Sharife & Political ecology: ID's environmental policies & $2009 / 04 / 17$ \\
\hline Khadija Sharife & Political ecology: DA's environmental policies & $2009 / 04 / 17$ \\
\hline Alex Matthews & Two-thirds gevaar' reasoned, not racist & $2009 / 04 / 19$ \\
\hline Hennie van Vuuren & Voting for accountability & $21 / 04 / 2009$ \\
\hline Khadija Sharife & Political ecology: IFP's environmental policies & $2009 / 04 / 21$ \\
\hline
\end{tabular}




\begin{tabular}{|l|l|l|}
\hline & African National Congress blog feed & \\
\hline Blogs & Blog post title & $\begin{array}{l}\text { Date } \\
\text { Posted }\end{array}$ \\
\hline Jessie Duarte & Elections are much more than just voting & $2009 / 03 / 02$ \\
\hline Janet Love & Fighting crime and its causes & $2009 / 03 / 03$ \\
\hline Cyril Ramaphosa & Democracy and the digital divide & $2009 / 03 / 03$ \\
\hline Nozizwe Madlala & Women and leadership & $2009 / 03 / 14$ \\
\hline Naledi Pandor & No-fee schools introduce free education for 7 million & $2009 / 03 / 19$ \\
\hline Cyril Ramaphosa & Holding government to account & $2009 / 03 / 23$ \\
\hline Jessie Duarte & The many ways to debate & $2009 / 03 / 23$ \\
\hline
\end{tabular}

\begin{tabular}{|l|l|l|}
\hline & Congress of the People blog feed & \\
\hline Blogs & Blog post title & $\begin{array}{l}\text { Date } \\
\text { Posted }\end{array}$ \\
\hline Masi Moyo & Chris I am voting COPE & $2009 / 03 / 14$ \\
\hline COPE & $\begin{array}{l}\text { Government should focus on creating employment, } \\
\text { says COPE }\end{array}$ & $2009 / 03 / 30$ \\
\hline Ronald Kete & A fresh mind in SA politics & $2009 / 04 / 15$ \\
\hline
\end{tabular}

\begin{tabular}{|l|l|l|}
\hline & Democratic Alliance blog feed & \\
\hline Blogs & Blog post title & $\begin{array}{l}\text { Date } \\
\text { Posted }\end{array}$ \\
\hline Administrator & Surprised? Shaik released on medical parole & $2009 / 03 / 03$ \\
\hline Administrator & $\begin{array}{l}\text { HPCSA to conduct an investigation into Schabir } \\
\text { Shaik's medical parole }\end{array}$ & $2009 / 03 / 10$ \\
\hline Administrator & Shaik parole - the next instalment & $2009 / 03 / 24$ \\
\hline Administrator & Guest blog: The ANC and corruption - the irony & $2009 / 03 / 30$ \\
\hline Administrator & The DA's Plan to fix the SAPS & $2009 / 04 / 03$ \\
\hline Administrator & Guest blog by Private Eye & $2009 / 04 / 07$ \\
\hline Administrator & $\begin{array}{l}\text { How the DA approach to crime stats will combat crime } \\
\text { in SA }\end{array}$ & $2009 / 04 / 09$ \\
\hline Administrator & Go out and vote on Wednesday 22 April! & $2009 / 04 / 20$ \\
\hline
\end{tabular}

